(2)

OPEN ACCESS

\title{
Transcarotid artery revascularization (TCAR): a technical video
}

\author{
Nanthiya Sujijantarat, ${ }^{1}$ Joseph Antonios, ${ }^{1}$ Andrew Koo, ${ }^{1}$ Daniela Renedo, ${ }^{1}$ \\ Branden J Cord (10 , ${ }^{2}$ Akli Zetchi, ${ }^{1}$ Ryan Hebert, ${ }^{1}$ Charles Matouk (D) ${ }^{1}$
}

Additional supplemental material is published online only. To view, please visit the journal online (http://dx.doi. org/10.1136/neurintsurg2021-018024)

'Department of Neurosurgery, Yale University School of Medicine, New Haven, Connecticut, USA ${ }^{2}$ Department of Neurosurgery, University of California Davis Health System, Sacramento, California, USA

\section{Correspondence to}

Dr Charles Matouk, Department of Neurosurgery, Yale University School of Medicine, New Haven, CT 06510, USA; charles. matouk@yale.edu

Received 14 July 2021

Accepted 23 August 2021

Check for updates

(c) Author(s) (or their employer(s)) 2021. Re-use permitted under CC BY-NC. No commercial re-use. See rights and permissions. Published by BMJ.

To cite: Sujijantarat $N_{\text {, }}$ Antonios J, Koo A, et al. J Neurolntervent Surg Epub ahead of print: [please include Day Month Year]. doi:10.1136/

neurintsurg-2021-018024

\begin{abstract}
Carotid revascularization is an important method of stroke prevention and includes carotid endarterectomy and transfemoral carotid angioplasty and stenting. More recently, a hybrid openendovascular approach, termed transcarotid artery revascularization (TCAR), is garnering increased attention. Although fundamentally a 'stenting procedure', unlike transfemoral carotid angioplasty and stenting, TCAR allows for a proximal neuroprotection strategy based on flow reversal. In this technical video, we will review operative techniques and nuances of the TCAR procedure, with a particular focus on the neurovascular proceduralist looking to adopt this technique into routine clinical practice(video 1).
\end{abstract}

Contributors NS wrote the abstract and edited the videos. JA filmed parts of the video and drew illustrative figure. AK and DR filmed the video clips. BJC, AZ, and RH helped with final editing. CM directed the script and carried out the procedure.

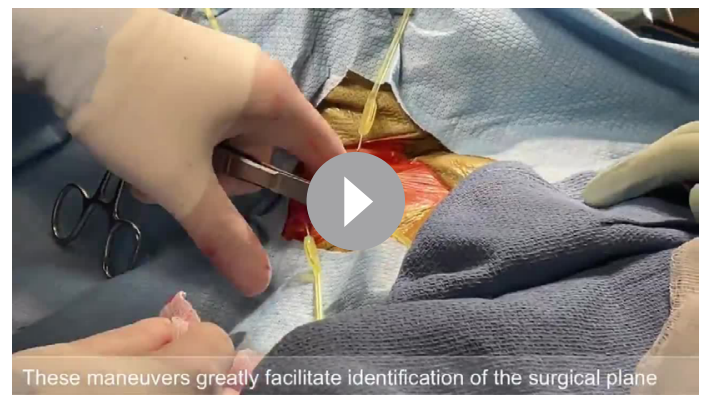

Video 1 TCAR Technical Video
Funding The authors have not declared a specific grant for this research from any funding agency in the public, commercial or not-for-profit sectors.

Competing interests BJC is a non-paid consultant for Silk Road Medical. CM receives NIH support from R21NS119992 from the National Institute of Neurological Disorders and Stroke. He serves as site-PI for the following carotid revascularization trials: TCAR-DWI

(Silk Road Medical) and CONFIDENCE (Microvention-Terumo). He is a non-paid consultant for Silk Road Medical.

Patient consent for publication Not required.

Ethics approval This study involves human participants but an Ethics Committee(s) or Institutional Board(s) exempted this study. An informed consent is attached.

Provenance and peer review Not commissioned; externally peer reviewed.

Supplemental material This content has been supplied by the author(s). It has not been vetted by BMJ Publishing Group Limited (BMJ) and may not have been peer-reviewed. Any opinions or recommendations discussed are solely those of the author(s) and are not endorsed by BMJ. BMJ disclaims all liability and responsibility arising from any reliance placed on the content. Where the content includes any translated material, BMJ does not warrant the accuracy and reliability of the translations (including but not limited to local regulations, clinical guidelines, terminology, drug names and drug dosages), and is not responsible for any error and/ or omissions arising from translation and adaptation or otherwise.

Open access This is an open access article distributed in accordance with the Creative Commons Attribution Non Commercial (CC BY-NC 4.0) license, which permits others to distribute, remix, adapt, build upon this work non-commercially, and license their derivative works on different terms, provided the original work is properly cited, appropriate credit is given, any changes made indicated, and the use is non-commercial. See: http:// creativecommons.org/licenses/by-nc/4.0/.

\section{ORCID iDs}

Branden J Cord http://orcid.org/0000-0002-9120-5989

Charles Matouk http://orcid.org/0000-0003-3234-9541 